\title{
Peran dan Kualitas Perkawinan Orang Tua terhadap Perilaku Anak Usia Dini
}

\author{
Lilis Suryani1, Farida Agus Setiawati ${ }^{1}{ }^{凶}$ \\ Psikologi, Universitas Negeri Yogyakarta, Indonesia ${ }^{(1)}$ \\ DOI: $10.31004 /$ obsesi.v6i2.1561
}

\begin{abstract}
Abstrak
Keluarga merupakan ruang lingkup pendidikan yang pertama dan utama pada anak, segala peristiwa yang terjadi dalam keluarga akan berdampak pada perkembangan perilaku anak. Anak yang tumbuh dari lingkungan yang positif cenderung mampu mengoptimalkan aspek perkembanggannya. Menggunakan pencarian literatur dan seleksi studi, artikel ini bertujuan untuk mengeksplor peran orang tua serta pengaruh kualitas perkawinan orang tua terhadap perilaku anak usia dini. Kriteria artikel yang digunakan adalah artikel yang membahas peran orang tua dan atau kualitas perkawinan orang tua dalam membentuk perilaku anak. Artikel diambil dari tahun 2012-2020 dengan bantuan mesin pencarian Cochrane, Science Direct, APA PsycNET, researchgate dan Scopus. Setelah dilakukukan screening, sebanyak 20 artikel memenuhi kriteria. Hasil analisis menunjukkan peran orang tua dalam pengasuhan serta kualitas perkawinan yang ditunjukkan pada anak berpengaruh terhadap perilaku anak usia dini.
\end{abstract}

Kata Kunci: kualitas perkawinan; peran orang tua; perilaku anak usia dini

\begin{abstract}
Family is the first and foremost scope of education for children, all events that occur in the family will have an impact on the development of the child's behavior. Children who grow up in a positive environment tend to be able to optimize their developmental aspects. Using literature review and study selection, this article aims to explore the role of parents as well as the influence of the quality of parental marriage on early childhood behavior. The criteria of the article used are articles that discuss the role of parents and or the quality of parents' marriage in shaping children's behavior. Articles taken from 2012-2020 with the help of search engines Cochrane, Science Direct, APA PsycNET, researchgate and Scopus. After the screening, 20 articles met the requirements. The results of the analysis show that the role of parents in parenting and the quality of marriage shown to children influenced the behavior of early childhood.
\end{abstract}

Keywords: quality of marriage; parental roles; early childhood behavior

Copyright (c) 2021 Lilis Suryani, Farida Agus Setiawati

$\triangle$ Corresponding author:

Email Address : lilissuryani.2019@student.uny.ac.id (Yogyakarta, Indonesia)

Received tanggal 19 February 2021, Accepted 23 July 2021, Published 28 July 2021 


\section{PENDAHULUAN}

Anak usia dini yang berada pada rentang usia 0-8 tahun disebut sebagai masa golden age (Montessori, 1964). Disebut sebagai masa golden age atau masa keemasan karena pada usia ini seluruh aspek perkembangan yang ada dalam diri anak mengalami peningkatan yang sangat pesat dibandingkan pada masa-masa selanjutnya. Berbagai penelitian menyatakan bahwa pada masa tersebut sebagian besar perkembangan otak anak mencapai $80 \%$ sedangkan $20 \%$ selanjutnnya akan berkembang setelah masa usia dini hingga usia 18 tahun. Implikasi dari sebuah paradigma pendidikan bahwa pembelajaran terjadi tidak hanya pada masa kanak-kanak, remaja dan dewasa, namun akan berlangsung seumur hidup (Eliasa, 2012).

Beberapa aspek perkembangan anak usia dini yang selanjutnya akan mempengaruhi perilaku anak ialah kognitif, bahasa, fisik motorik, sosial dan emosional (Hastings \& Grady, 2016). Seluruh aspek tersebut akan berkembang dengan optimal jika lingkungan memberikan respons yang positif bagi anak, karena pengaruh yang paling kuat dalam perkembangan anak adalah keluarga (Christian et al., 1998; Turney \& McLanahan, 2015a). Jika lingkungan memberikan respons yang negatif tentu perkembangan perilaku anak akan terganggu (Miragoli, Balzarotti, Camisasca, \& Di Blasio, 2018). Dengan kata lain, berbagai pengaturan lingkungan, baik lingkungan terdekat maupun jauh secara langsung berkaitan dengan proses perkembangan individu (Bronfenbrenner, 1986).

Dalam perkembangannya, lingkungan terdekat anak ialah keluarga yang didalamnya terdapat orang tua. Peran orang tua dalam mendidik anak sangat penting dan mempengaruhi perkembangan perilaku anak. Terdapat beberapa penelitian mengenai peran orang tua terhadap perilaku anak (Chan \& Lam, 2017; Lunkenheimer et al., 2017; Sawrikar et al., 2018; Serbin et al., 2015a; Xuan et al., 2018). Bahkan sejak anak dalam kandungan perilaku yang ditunjukkan oleh orang tua terhadap anak dapat mempengaruhi perilaku anak pada kehidupan selanjutnya (Leung \& Suskind, 2020). Pengalaman kehidupan awal yang positif tentu dapat membantu mecegah depresi anak dikemudian hari. Hal tersebut ditemukan dalam sebuah penelitian yang menunjukkan hasil antara keterlibatan orang tua yang positif pada masa kanak-kanak sehubungan dengan depresi pada awal masa dewasa (Cong et al., 2020; Rosales et al., 2019).

Selain peran orang tua, kualitas perkawinan yang ditunjukkan orang tua dalam sebuah keluarga tentu akan mempengaruhi perilaku anak (Elam et al., 2017; Stroud et al., 2015). Perkawinan merupakan suatu tahap penting yang diinginkan hampir pada setiap individu. Perkawinan adalah penyatuan sosial antara manusia hingga membentuk satu tali kekeluargaan (Karney, 2015). Di satu sisi, perkawinan mempunyai dampak positif bagi pasangan yang menikah (Aarskaug Wiik et al., 2012; Hansen et al., 2007; Soons \& Liefbroer, 2008; Yu et al., 2020), namun di sisi lain perkawinan mempunyai dampak negatif yang menimbulkan penderitaan karena terjadi perceraian dan kekerasan dalam rumah tangga (Anderberg et al., 2018; Barham et al., 2009; DeLongis \& Zwicker, 2017; Shor et al., 2012). Tingginya angka perceraian disebabkan oleh kualitas perkawinan yang rendah (Amato, 1999; DeLongis \& Zwicker, 2017; Wilson et al., 2018).

Kualitas perkawinan adalah penilaian subjektif dari hubungan antara pasangan. Umumnya, kualitas perkawinan diukur dengan memeriksa interaksi dalam hubungan atau perasaan responden tentang dan evaluasi hubungan mereka. Kualitas perkawinan sering dianggap multidimensi, dan dapat diukur pada dimensi positif misal kepuasan, kebahagiaan dan dimensi negatif yaitu konflik (Lucas, 2016). Kualitas perkawinan menjadi topik yang menarik perhatian peneliti dalam studi perkawinan, karena pengaruhnya yang penting terhadap hubungan suami istri serta kehidupan seseorang dalam satu kesatuan keluarga secara keseluruhan.

Kualitas perkawinan mempengaruhi perilaku anak, baik anak usia bayi maupun anak usia dini (McHale et al., 1998). Penelitian menunjukan hubungan perkawinan pada keterampilan sosial anak-anak dengan teman sebaya (Roopnarine et al., 1990). Temuan dari penelitian menunjukkan bahwa kualitas perkawinan dan temperamen anak terkait erat 
dengan kualitas coparenting (Christopher et al., 2015; Elam et al., 2017; Fan et al., 2020a). Berbeda dengan sebuah penelitian yang dilakukan oleh Chang et al (2004) yang menunjukkan bahwa efek dari kualitas perkawinan pada perilaku eksternalisasi anak tidak langsung mempengaruhi, namun di mediasi melalui pengasuhan.

Berdasarkan beberapa pernyataan diatas, dapat dikatakan bahwa peran orang tua dan kualitas perkawinan orang tua merupakan faktor yang mempengaruhi perilaku anak usia dini. Peran orang tua dalam membentuk perilaku anak antara lain memenuhi kebutuhan anak, menyediakan lingkungan yang aman, melindungi anak, mendidik anak, memperkenalkan anak pada lingkungan, menjadi contoh bagi anak, memperkenalkan tanggung jawab pada anak, membimbing anak, mendukung dan memotivasi anak, memperhatikan kemampuan sosial emosional anak, mendisiplinkan anak dengan lembut, menetapkan batas dan aturan, mengajarjan anak untuk lebih asertif, membangun kematangan pribadi anak, menjaga kondisi fisik anak. Sedangkan kualitas perkawinan yang dapat mempengaruhi perilaku anak antara lain kebahagiaan dan kepuasan perkawinan (Tyas \& Herawati, 2017).

Artikel ini menyajikan hasil meta-analisis penelitian sebelumnya atau kajian mendalam tentang pengaruh kualitas perkawinan dan peran orang tua dalam mengembangkan perilaku anak usia dini. Peran orang tua dalam pengasuhan anak usia dini tentunya memerlukan beberapa strategi yang dapat dilakukan. Program pengasuhan yang mendukung harus dilaksanakan oleh ibu dan ayah (Yang et al., 2020).

\section{METODOLOGI}

- Cochrane, Science Direct, APA PsycNET, researchgate dan Scopus.

- Jurnal peran orang tua dalam mengembangkan perilaku anak $(2015-2017, n=100)$

- Jurnal kualitas perkawinan dalam mengembangkan perilaku anak (2012-2020, n=100)

$\downarrow$

- Jurnal peran orang tua dalam mengembangkan perilaku anak, $(n=10)$

- Jurnal kualitas perkawinan dalam mengembangkan perilaku anak, $(n=10)$

\begin{tabular}{|l|l|l|}
\hline \multicolumn{1}{|c|}{$\begin{array}{l}\text { Abstrak yang lolos seleksi } \\
\left(n_{1}=61, n_{2}=69\right)\end{array}$} & $\begin{array}{l}\text { Abstrak yang tidak lolos seleksi } \\
\left(n_{1}=39, n_{2}=31\right)\end{array}$ \\
\hline $\begin{array}{l}\text { Artikel yang lolos seleksi } \\
\left(n_{1}=10, n_{2}=10\right)\end{array}$ & $\begin{array}{l}\text { Artikel yang tidak dapat di akses. }\left(n_{1}=\right. \\
\left.41, n_{2}=49\right) \\
\text { Alasannya : } \\
\text { Matrik korelasi yang digunakan } \\
\text { untuk analisis } \\
\left(n_{1}=10 \text { judul penelitian) }\right.\end{array}$ \\
\hline
\end{tabular}

Gambar 1. Diagram alur mengenai pencarian literatur dan seleksi studi

Metode pencarian literatur dan seleksi studi merupakan rangkuman menyeluruh beberapa studi penelitian yang ditentukan berdasarkan tema tertentu. Tema artikel yang digunakan dalam penelitian ini adalah peran orang tua dalam membentuk perilaku anak dan pengaruh kualitas pernikahan dalam membentuk perilku anak. Untuk mendapatkan sumber 
analisis yang kredibel, peneliti melakukan pencarian literatur dan seleksi studi menggunakan bantuan mesin pencari Cochrane, Science Direct, APA PsycNET, researchgate dan Scopus. Jenis artikel yang digunakan adalah artikel yang terbit dari tahun 2012-2020. Menggunakan kata kunci peran orang tua, kualitas perkawinan dan perilaku anak, terdapat 200 artikel yang ditemukan. Kata kunci tersebut kemudian dikombinasikan agar sesuai dengan tema penelitian. Tujuannya untuk memperluas dan menspesifikakan pencarian sehingga mempermudah penentuan artikel yang memenuhi kriteria. Pencarian literatur dan seleksi studi dalam penelitian ini menggunakan PRISMA statement sebagaimana dapat dilihat pada gambar 1 .

\section{HASIL DAN PEMBAHASAN}

Berdasarkan hasil pencarian literatur di lima database menggunakan kata kunci yang sudah disesuaikan, terdapat 200 artikel yang didapat. Hasil data penelitian yang dimasukkan dalam kajian literatur dan seleksi studi dalam penelitian ini adalah rangkuman dari artikel yang didokumentasikan terkait peran orang tua yang disajikan pada Tabel 1 (lampiran 1) dan kualitas perkawinan dalam mengembangkan perilaku anak yang disajikan pada Tabel 2 (lampiran 1). Sebelum dilakukan analisis, artikel yang didapat melewati tahap uji skrining terlebih dahulu. Dari 200 artikel yang ada, sebanyak 60 artikel diekslusi karena duplikasi. Peneliti kemudian melakukan skrining berdasarkan judul, abstrak dan full text yang disesuaikan dengan tema penelitian. Asesmen yang dilakukan berdasarkan uji kelayakan didapatkan sebanyak 20 artikel yang memenuhi kriteria.

\section{Peran orang tua}

Dalam proses kemandiriannya, anak masih membutuhkan bantuan, pendampingan, dan teladan yang baik melalui kualitas pendidikan di dalam rumah (Varela Londoño et al., 2019). Seorang anak dapat memiliki awal kehidupan yang baik ketika ia tumbuh dalam lingkungan pengasuhan yang mestimulasi dan mendukung kebutuhan esensialnya seperti nutrisi, kesehatan dan keamanan seperti juga dengan kebutuhan psikologis, sosial, spiritual dan intelektual. Hal ini memberikan kesempatan yang sangat besar bagi anak untuk dapat mengoptimalkan potensinya di kemudian hari (World Health Organization, 2012). Peran orang tua dalam pendidikan anak diberikan melalui pendidikan dasar, sopan santun, dan keterampilan dasar seperti pendidikan agama, etika, sopan satun dan mengajarkan perilaku bernilai seperti yang diajarkan di sekolah (Setiawan et al., 2020). Orang tua yang memiliki hubungan emosional yang positif akan lebih mendukung, mendorong dan memfasilitasi anak-anak mereka karena orang tua mengharapkan kualitas daripada kuantitas anak. Oleh karena itu, kualitas pengasuhan yang diberikan orang tua dianggap penting untuk memahami mengapa beberapa anak mengalami perilaku bermasalah sementara yang lain berkembang normal (Vieira et al., 2016).

Salah satu teori perkembangan anak-teori kelekatan-dapat digunakan untuk melihat hubungan orang tua-anak sejak dini serta bagaimana bentuk dukungan yang diberikan. Menurut teori tersebut, hubungan orang tua-anak di awal masa perkembangan merupakan dasar bagi fungsi sosial, emosional, dan sekolah anak di kemudian hari (Appleyard, 2007). Isu-isu mendasar terkait keamanan dan perlindungan; dalam istilah psikologis, berfokus pada sejauh mana pemberian perlindungan akan ancaman dan rasa aman (O \& Scott, n.d.). Tokoh awal yang dianggap penting dalam pengasuhan adalah ibu-meski peran gender dalam keluarga selalu berubah setiap tahunnya, perempuan masih dianggap sebagai sosok yang paling bertanggung jawab merawat kebutuhan harian anak di awal masa kanak-kanak (Mccoy et al., 2013b ) - tetapi dalam perkembangannya, teman sebaya dan kemudian pasangan menjadi tokoh sentral kelekatan dan perilaku keterikatan langsung (Doinita \& Maria, 2015).

Perkembangan sosial emosional di masa kanak-kanak terdiri dari dua tugas perkembangan, yaitu keterlibatan positif dengan teman sebaya serta pengelolaan emosi dan 
ekspresi. Aspek sosial emosional dipengaruhi oleh faktor biologis dan pengalaman. Dua hal ini secara bersamaan membentuk struktur otak, gen memberikan "instruksi" untuk tubuh sedangkan pengalaman mempengaruhi bagaimana instruksi dilaksanakan (Palmer, n.d.). Tidak ada aturan baku dalam mengukur dua hal tersebut, namun biasanya diukur melalui penilaian orang tua dan guru terhadap perilaku anak. Emosi dan kesejahteraan anak usia dini secara langsung dan tidak langsung dipengaruhi berbagai elemen seperti pengasuhan, hubungan orang tua, dan peran orang tua (Turney \& McLanahan, 2015b). Ketika ibu memperlakukan seorang anak sebagai anak yang lamban, dianggap tidak mampu dan sering di abaikan, tingkat kecemasan anak akan meningkat yang mana akan mempengaruhi perilaku, sering takut, merasa tidak aman dan harga dirinya rendah (Tolliver-Lynn et al., 2021).

Begitu juga dengan cara orang tua menyeimbangkan perannya sebagai pekerja dan anggota keluarga diasosisasikan dengan kualitas hubungan orang tua dan anak, yang kemudian dikaitkan dengan permasalahan internalisasi dan eksternalisasi pada anak (Vieira et al., 2016). Meski begitu, permasalahan perilaku internalisasi dan eksternalisasi pada anak tidak hanya dipengaruhi peran orang tua saja, banyak dimensi yang saling berkaitan $(\mathrm{O} \&$ Scott, n.d.). Anak yang mengalami masalah internalisasi (seperti pemalu dan menarik diri dari lingkungan) yang melekat hingga dewasa, membuat mereka lebih sulit dalam berinteraksi dan belajar dengan sebayanya. Ketika kualitas hubungan orang tua dan anak rendah, depresi dan kecemasan yang dialami orang tua memperburuk kecemasan anak di masa kecil (Maddison N. Tolliver-Lynn, 2020). Hal ini membuat sebagian orang tua tidak menganggap kecemasan sebagai hal yang perlu ditangani dan lebih memilih perilaku yang dianggap bisa ditangani seperti masalah kemandirian dan sekolah. Sebaliknya orang tua yang dapat merespon secara adaptif masalah perilaku anaknya dengan memberikan dukungan dapat membantu mengurangi tingkat keparahan anak mereka (Serbin et al., 2015b).

Sedangkan anak dengan permasalahan perilaku eksternalisasi seperti agresif, berteriak, bertengkar, sering melanggar peraturan akan kurang terlibat dalam pembelajaran dibandingkan teman-temannya. Anak yang mengalami permasalahan perilaku saat berusia 3 tahun mungkin tidak dapat menguasai kemampuan akademik baru maupun meningkatkan kemampuan yang ada, yang suatu saat membuat ia mengalami kesulitan kognitif saat memasuki masa sekolah. Hal ini mengindikasikan bahwa orang tua dan lingkungan sekitar rumah memegang peran penting dalam membentuk perilaku yang menghambat pembelajaran. Sedangkan di usia 5 tahun, guru dan lingkungan sekolah menjadi tokoh penting dalam hubungan antara masalah perilaku anak dan pembelajaran (Turney \& McLanahan, 2015b). Meski begitu, Serbin, L. A et al menganggap orang tua masih memegang peran penting dalam membentuk perilaku ekternalisasi anak di awal usia sekolah. Dukungan dan hubungan orang tua yang rendah serta pola pengasuhan yang buruk dapat memperburuk permaslahan eksternalisasi anak hingga berlanjut dalam jangka lama. Meskipun anak perempuan dan laki-laki memiliki perilaku eksternalisasi yang berbeda, proses timbal balik keduanya tidak berbeda dalam kaitannya dengan gender (Serbin, L. A et al).

Hubungan antara orang tua dan anak dapat dipererat melalui pendidikan karakter. Penanaman pendidikan karakter pada anak usia dini dapat dilakukan orang tua dengan memberikan dukungan di sekolah, mengajak anak bercerita, bermain musik dan belajar kesenian (Chou, Mei-Ju, 2014). Peran perhatian, afeksi dan kemanan yang diberikan orang tua secara langsung mempengaruhi pendidikan karakter anak. Semakin tinggi perhatian yang diberikan maka semakin tinggi juga pendidikan karakter anak (Chou, Mei-Ju, 2014). Sayangnya beberapa orang tua mengalami kesulitan dalam menyeimbangkan tuntutan pekerjaan dan keluarga sehingga berdampak pada hubungan dan pengalaman keluarga, khususnya bagi mereka yang memiliki anak kecil yang menuntut perhatian dan dukungan lebih dari orang tuanya. Kondisi stres kerja seperti tertekan, overload dan lingkungan kerja yang negatif mengakibatkan rendahnya keterlibatan orang tua dan tingginya penarikan diri 
dari anak. Sedangkan orang tua dengan lingkungan kerja yang lebih kompleks dan menantang cenderung mampu menyediakan lingkungan rumah yang lebih positif dengan stimulasi intelektual, hangat, responsif dan jarang memberikan hukuman (Vieira et al., 2016). Selain itu, tingkat pendidikan orang tua juga berpengaruh terhadap kemampuan sosial anak, semakin tinggi tingkat pendidikan ibu maka semakin tinggi tingkat keaktifan dan kontrol diri pada anak (Yuksel \& Canel, 2012b) serta semakin bagus adaptasi anak di lingkungan sekolah. Hasil ini mendukung teori sistem keluarga yang menunjukkan bahwa karakteristik demografi keluarga secara tidak langsung mempengaruhi perkembangan anak melalui perilaku pengasuhan (Akçinar, 2013).

\section{Kualitas Perkawinan}

Kepuasan, keharmonisan, kehangatan, dan kebahagiaan perkawinan orang tua tentu menjadi nilai tersendiri dalam kualitas perkawinan. Dalam studi seputar perkawinan, konsep mengenai kualitas perkawinan sangatlah beragam (Dush et al., 2008). Beberapa aspek yang sering digunakan adalah kebahagiaan perkawinan, kepuasan perkawinan, stabilitas perkawinan, kesuskesan perkawinan, penyesuaian perkawinan, pertemanan dan beberapa terminologi lain yang menjelaskan kualitas hubungan dan sering digunakan untuk menjelaskan kualitas perkawinan (Nurhayati et al., 2019). Peran kualitas perkawinan dalam sebuah keluarga menjadi dinamis seiring pertumbuhan seorang anak dan akan terlihat menonjol selama bulan-bulan pertama kehidupan anak (Fan et al., 2020b) begitu juga dengan kepuasan perkawinan. Dalam penelitian (Yuksel \& Canel, 2012b), kepuasan perkawinan mulai menurun setelah kelahiran bayi pertama sementara konflik antar pasangan semakin meningkat. Menurut (Mccoy et al., 2013b) konflik perkawinan dibagi menjadi dua yaitu konflik konstruktif dan konflik destruktif. Kedua konflik ini memiliki efek yang berbeda terhadap kualitas fungsi keluarga dan penyesuaian diri anak. Konflik perkawinan yang konstruktif dihubungkan dengan praktek pengasuhan positif sedangkan konflik perkawinan destruktif dihubungkan dengan pengasuhan negatif dan berdampak buruk pada hubungan anak dengan teman sebaya maupun saudaranya (Yuksel \& Canel, 2012b).

Ketika anak memasuki masa prasekolah, ikatan keluarga rentan melemah karena mengalami stres tingkat tinggi, sulit beradaptasi dalam perannya sebagai orang tua (Yuksel \& Canel, 2012b) dan anak mulai mengalami masalah perilaku (Neece et al., 2012). Persepsi orang tua terhadap anaknya yang bermasalah berkorelasi positif terhadap ketiga kompenen dalam stress pengasuhan, yaitu tekanan orang tua, evaluasi hubungan antara orang tua-anak yang lebih disfungsional dan anak dianggap semakin sulit dikendalikan (Miragoli, Balzarotti, Camisasca, \& di Blasio, 2018). Sebaliknya jika anak di anggap baik maka berkorelasi positif terhadap kepuasan perkawinan dan tingkat depresi orang tua mereka (Yuksel \& Canel, 2012b). Selain itu, status kesejahteraan orang tua secara langsung dan tidak langsung berpengaruh kepada anak melalui ketidakpuasan perkawinan dan ini membahayakan penyesuaian diri mereka.

\section{SIMPULAN}

Seorang anak dapat memiliki awal kehidupan yang baik ketika ia tumbuh dalam lingkungan pengasuhan yang mestimulasi dan mendukung kebutuhannya. Orang tua sebagai lingkungan terdekat anak berperan penting dalam membentuk perilaku anak di kemudian hari. Orang tua yang memiliki hubungan emosional yang positif akan lebih mendukung, mendorong dan memfasilitasi anak-anak mereka karena mengharapkan kualitas daripada kuantitas anak. Seiring pertumbuhan anak, kualitas perkawinan orang tua akan semakin dinamis dan banyak konflik yang terjadi. Konflik perkawinan yang konstruktif dihubungkan dengan praktek pengasuhan positif sedangkan konflik perkawinan destruktif dihubungkan dengan pengasuhan negatif dan berdampak buruk pada hubungan anak dengan teman sebaya maupun saudaranya. 


\section{UCAPAN TERIMA KASIH}

Penulis mengucapkan terima kasih kepada Universitas Negeri Yogyakarta khususnya program studi pascasarjana yang telah membantu penyelesaiaan artikel ini.

\section{DAFTAR PUSTAKA}

Aarskaug Wiik, K., Keizer, R., \& Lappegård, T. (2012). Relationship Quality in Marital and Cohabiting Unions Across Europe. Journal of Marriage and Family, 74(3), 389-398. https://doi.org/10.1111/j.1741-3737.2012.00967.x

Amato, P. R. (1999). Do Attitudes Toward Divorce Affect Marital Quality? Feminism and Psychology, 8(1), 58-75. https:// doi.org/10.1177/019251399020001004

Anderberg, D., Rainer, H., \& Roeder, K. (2018). Family-specific investments and divorce with dynamically inconsistent households: Marital contracts and policy. Journal of Economic Behavior and Organization, 148, 199-225. https://doi.org/10.1016/i.jebo.2018.02.019

Barham, V., Devlin, R. A., \& Yang, J. (2009). A theory of rational marriage and divorce. European Economic Review, 53(1), 93-106. https://doi.org/10.1016/j.euroecorev.2008.02.002

Bronfenbrenner, U. (1986). Ecology of the family as a context for human development. $\begin{array}{lll}\text { Developmental } & \text { Psychology, } & \text { 723-742. }\end{array}$ https://doi.org/10.1037/0012-1649.22.6.723

Chan, T. O., \& Lam, S. F. (2017). Mediator or moderator? The role of mindfulness in the association between child behavior problems and parental stress. Research in Developmental Disabilities, 70(March), 1-10. https://doi.org/10.1016/j.ridd.2017.08.007

Chang, L., Lansford, J. E., Schwartz, D., \& Farver, J. A. M. (2004). Marital quality, maternal depressed affect, harsh parenting, and child externalising in Hong Kong Chinese families. International Journal of Behavioral Development, 28(4), 311-318. https://doi.org/10.1080/01650250344000523

Christian, K., Morrison, F. J., \& Bryant, F. B. (1998). Predicting kindergarten academic skills: Interactions among child care, maternal education, and family literacy environments. Early Childhood Research Quarterly, 13(3), 501-521. https://doi.org/10.1016/S08852006(99)80054-4

Christopher, C., Umemura, T., Mann, T., Jacobvitz, D., \& Hazen, N. (2015). Marital Quality over the Transition to Parenthood as a Predictor of Coparenting. Journal of Child and Family Studies, 24(12), 3636-3651. https:// doi.org/10.1007/s10826-015-0172-0

Cong, X., Hosler, A. S., Tracy, M., \& Appleton, A. A. (2020). Journal of A ff ective Disorders The relationship between parental involvement in childhood and depression in early adulthood. Journal of Affective Disorders, 273(May 2019), 173-182. https://doi.org/10.1016/j.jad.2020.03.108

DeLongis, A., \& Zwicker, A. (2017). Marital satisfaction and divorce in couples in stepfamilies. $\begin{array}{llll}\text { Current Opinion in } & \text { Psychology, 13, } 161 .\end{array}$ https://doi.org/10.1016/j.copsyc.2016.11.003

Elam, K. K., Chassin, L., Eisenberg, N., \& Spinrad, T. L. (2017). Marital stress and children's externalizing behavior as predictors of mothers' and fathers' parenting. Development and Psychopathology, 29(4), 1305-1318. https:// doi.org/10.1017/S0954579416001322

Eliasa, E. I. (2012). Counsellor Roles on Students' Lifelong Learning Understanding (A Psychological Study Based on Ecological System Theory). Procedia - Social and Behavioral Sciences, 46(1), 5703-5706. https:/ / doi.org/10.1016/j.sbspro.2012.06.501

Fan, J., Ren, L., \& Li, X. (2020). Contributions of child temperament and marital quality to coparenting among Chinese families. Children and Youth Services Review, 108, 104610. https://doi.org/10.1016/j.childyouth.2019.104610 
Hanetz Gamliel, K., Dollberg, D. G., \& Levy, S. (2018). Relations Between Parents' Anxiety Symptoms, Marital Quality, and Preschoolers' Externalizing and Internalizing Behaviors. Journal of Child and Family Studies, 27(12), 3952-3963. https:// doi.org/10.1007/s10826-018-1212-3

Hansen, T., Moum, T., \& Shapiro, A. (2007). Relational and individual well-being among cohabitors and married individuals in midlife: Recent trends from Norway. Journal of Family Issues, 28(7), 910-933. https:// doi.org/10.1177/0192513X07299610

Hastings, P. D., \& Grady, J. S. (2016). Socialization in infancy and early childhood. In The Curated Reference Collection in Neuroscience and Biobehavioral Psychology (Vol. 3). Elsevier. https:/ / doi.org/10.1016/B978-0-12-809324-5.21839-7

Jiang, Z., Waters, A. C., Liu, Y., Li, W., \& Yang, L. (2017). Event-related theta oscillatory substrates for facilitation and interference effects of negative emotion on children's cognition. International Journal of Psychophysiology, 116, 26-31. https:// doi.org/10.1016/j.ijpsycho.2017.02.012

Karney, B. R. (2015). Personality and Marriage. In International Encyclopedia of the Social \& Behavioral Sciences: Second Edition (Second Edi, Vol. 16). Elsevier. https:// doi.org/10.1016/B978-0-08-097086-8.25026-5

Leung, C. Y. Y., \& Suskind, D. L. (2020). What Parents Know Matters: Parental Knowledge at Birth Predicts Caregiving Behaviors at 9 Months. Journal of Pediatrics, 1-9. https:// doi.org/10.1016/i.jpeds.2019.12.021

Lucas, A. (2016). Marital Quality. Encyclopedia of Family Studies. https:// doi.org/10.1002/9781405165518.wbeosm029

Lunkenheimer, E., Ram, N., Skowron, E. A., \& Yin2, P. (2017). Harsh Parenting, Child Behavior Problems, and the Dynamic Coupling. 31(6), 689-698. https://doi.org/10.1037/fam0000310

Mccoy, K. P., George, M. R. W., Cummings, E. M., \& Davies, P. T. (2013). Constructive and destructive marital conflict, parenting, and children's school and social adjustment. Social Development, 22(4), 641-662. https:/ / doi.org/10.1111/sode.12015

McHale, J. L., Frosch, C. A., \& Mangelsdorf, F. S. C. (1998). A multiple method approach to temperament from infancy to early childhood associations with parental involvement and marital quality. Infant Behavior and Development, 21, 568. https:// doi.org/10.1016/S0163-6383(98)91781-7

Miragoli, S., Balzarotti, S., Camisasca, E., \& Di Blasio, P. (2018). Parents' perception of child behavior, parenting stress, and child abuse potential: Individual and partner influences. Child Abuse and Neglect, 84(March), 146-156. https://doi.org/10.1016/j.chiabu.2018.07.034

Pedro, M. F., Ribeiro, T., \& Shelton, K. H. (2012). Marital satisfaction and partners' parenting practices: The mediating role of coparenting behavior. Journal of Family Psychology, 26(4), 509-522. https:// doi.org/10.1037/a0029121

Robinson, M., \& Neece, C. L. (2015). Marital Satisfaction, Parental Stress, and Child Behavior Problems among Parents of Young Children with Developmental Delays. Journal of Mental Health Research in Intellectual Disabilities, 8(1), 23-46. https:// doi.org/10.1080/19315864.2014.994247

Roopnarine, J. L., Church, C. C., \& Levy, G. D. (1990). Day care children's play behaviors: Relationship to their mothers' and fathers' assessments of their parenting behaviors, marital stress, and marital companionship. Early Childhood Research Quarterly, 5(3), 335-346. https:// doi.org/10.1016/0885-2006(90)90025-V

Rosales, A., Sargsyan, V., Abelyan, K., Hovhannesyan, A., Ter-Abrahanyan, K., Jillson, K. Q., \& Cherian, D. (2019). Behavior change communication model enhancing parental practices for improved early childhood growth and development outcomes in rural Armenia - A quasi-experimental study. Preventive Medicine Reports, 14(February), 100820. https://doi.org/10.1016/j.pmedr.2019.100820 
Sawrikar, V., Hawes, D. J., Moul, C., \& Dadds, M. R. (2018). The role of parental attributions in predicting parenting intervention outcomes in the treatment of child conduct problems. Behaviour Research and Therapy, 111, 64-71. https://doi.org/10.1016/j.brat.2018.10.004

Serbin, L. A., Kingdon, D., Ruttle, P. L., \& Stack, D. M. (2015). The impact of children's internalizing and externalizing problems on parenting: Transactional processes and reciprocal change over time. Development and Psychopathology, 27(4), 969-986. https://doi.org/10.1017/S0954579415000632

Shor, E., Roelfs, D. J., Bugyi, P., \& Schwartz, J. E. (2012). Meta-analysis of marital dissolution and mortality: Reevaluating the intersection of gender and age. Social Science and Medicine, 75(1), 46-59. https:// doi.org/10.1016/j.socscimed.2012.03.010

Soons, J. P. M., \& Liefbroer, A. C. (2008). Together is better? Effects of relationship status and resources on young adults' well-being. Journal of Social and Personal Relationships, 25(4), 603-624. https:/ / doi.org/10.1177/0265407508093789

Stroud, C. B., Meyers, K. M., Wilson, S., \& Durbin, C. E. (2015). Marital Quality Spillover and Young Children's Adjustment: Evidence for Dyadic and Triadic Parenting as Mechanisms. Journal of Clinical Child and Adolescent Psychology, 44(5), 800-813. https://doi.org/10.1080/15374416.2014.900720

Turney, K., \& McLanahan, S. (2015). The academic consequences of early childhood problem behaviors. Social Science Research, 54, 131-145. https://doi.org/10.1016/j.ssresearch.2015.06.022

Tyas, F. P. S., \& Herawati, T. (2017). Kualitas Pernikahan dan Kesejahteraan Keluarga Menentukan Kualitas Lingkungan Pengasuhan Anak Pada Pasangan yang Menikah Usia Muda. Jurnal Ilmu Keluarga Dan Konsumen, 10(1), 1-12. https://doi.org/10.24156/jikk.2017.10.1.1

Wilson, S. J., B E Bailey, M., W B Malarkey, M., \& and J K Kiecolt-Glaser, P. (2018). Innovation in Aging , 2018, Vol. 2, No. S1. 2(1), 38-39. https://doi.org/10.1093/geroni/igy023.3123

Xuan, X., Chen, F., Yuan, C., Zhang, X., Luo, Y., Xue, Y., \& Wang, Y. (2018). The relationship between parental conflict and preschool children's behavior problems: A moderated mediation model of parenting stress and child emotionality. Children and Youth Services Review, 95, 209-216. https:// doi.org/10.1016/j.childyouth.2018.10.021

Yang, X., Ke, S., \& Gao, L. L. (2020). Social support, parental role competence and satisfaction among Chinese mothers and fathers in the early postpartum period: A cross-sectional study. Women and Birth, 33(3), e280-e285. https://doi.org/10.1016/j.wombi.2019.06.009

Yu, Y., Wu, D., Wang, J. M., \& Wang, Y. C. (2020). Dark personality, marital quality, and marital instability of Chinese couples: An actor-partner interdependence mediation model. Personality and Individual Differences, 154(August). https:// doi.org/10.1016/j.paid.2019.109689

Yuksel, M., \& Canel, A. N. (2012). The Analysis of Social Competency and Anti-social Behaviors of Children Aged Between 4 and 5 from the Perspective of Marital Satisfaction and Some Other Variables. Procedia - Social and Behavioral Sciences, 46, 4973-4980. https://doi.org/10.1016/j.sbspro.2012.06.370 


\section{Lampiran 1}

Tabel 1. Artikel peran orang tua dalam mengembangkan perilaku anak

\begin{tabular}{|c|c|c|c|c|}
\hline No & Nama Penulis & $\begin{array}{c}\text { Subjek } \\
\text { Penelitian }\end{array}$ & Variabel & Hasil \\
\hline 1 & $\begin{array}{l}\text { Turney, K., \& } \\
\text { McLanahan, S } \\
\text { (2015) }\end{array}$ & $\begin{array}{l}\text { Orang tua yang } \\
\text { memiliki anak } \\
\text { usia } 1,3,5 \text { dan } 9 \\
\text { tahun } \\
\mathrm{N}=2302\end{array}$ & $\begin{array}{l}\text { Kemampuan } \\
\text { sosial/emosional } \\
\text { (diukur melalui } \\
\text { permasalahan } \\
\text { internalisasi, } \\
\text { eksternalisasi dan } \\
\text { atensi pada anak) } \\
\text { terhadap } \\
\text { perkembangan } \\
\text { kognitif }\end{array}$ & $\begin{array}{l}\text { - Masalah eksternalisasi dan perhatian } \\
\text { pada usia } 3 \text { dan } 5 \text { tahun, berhubungan } \\
\text { dengan perkembangan kognitif yang } \\
\text { buruk pada masa kanak-kanak } \\
\text { - Keterlibatan orang tua berperan } \\
\text { penting pada masalah perilaku } \\
\text { eksternalisasi dan perkembangan } \\
\text { kognitif anak usia } 3 \text { tahun. }\end{array}$ \\
\hline 2 & $\begin{array}{l}\text { Serbin, L. A et al } \\
\text { (2015) }\end{array}$ & $\begin{array}{l}\text { Pasangan ibu- } \\
\text { anak (N 1/4 138; } \\
65 \text { anak laki- } \\
\text { laki) }\end{array}$ & $\begin{array}{l}\text { Pola asuh, perilaku } \\
\text { anak }\end{array}$ & $\begin{array}{l}\text { Kualitas pengasuhan menjadi penting } \\
\text { untuk mengetahui mengapa sebagian } \\
\text { anak mengalami perilaku bermasalah } \\
\text { sedangkan lainnya berkembang } \\
\text { normal }\end{array}$ \\
\hline 3 & $\begin{array}{l}\text { Joko Ansari } \\
\text { Setiawan1, } \\
2020\end{array}$ & $\begin{array}{l}157 \text { orang tua } \\
\text { dan anak usia } \\
\text { dini }\end{array}$ & $\begin{array}{l}\text { Perhatian orang tua } \\
\text { terhadap } \\
\text { pendidikan } \\
\text { karakter anak }\end{array}$ & $\begin{array}{l}\text { - Semakin tinggi perhatian, kasih } \\
\text { sayang dan keamanan yang diberikan } \\
\text { orang tua secara langsung } \\
\text { berpengaruh terhadap pendidikan } \\
\text { karakter anak usia dini } \\
\text { - Semakin tinggi perhatian dan kasih } \\
\text { sayang orang tua maka semakin } \\
\text { tinggi pula pendidikan karakter anak } \\
\text { usia dini }\end{array}$ \\
\hline 4 & $\begin{array}{l}\text { Yue Yu, } \\
(2017)\end{array}$ & $\begin{array}{l}\text { Analisis } 2166 \\
\text { pertanyaan } \\
\text { daari } 166 \text { orang } \\
\text { tua dengan } \\
\text { usia anak } \\
\text { antara } 2-6 \\
\text { tahun }\end{array}$ & $\begin{array}{l}\text { Pertanyaan } \\
\text { pedagogik pada } \\
\text { anak usia dini }\end{array}$ & $\begin{array}{l}\text {-Langkah pertama untuk mengetahui } \\
\text { peran orang tua-anak adalah dengan } \\
\text { mengetahui kualitas pertanyaan yang } \\
\text { diberikan dalam menstimulasi } \\
\text { pendidikan anak } \\
\text {-Pertanyaan pedagogik yang } \\
\text { diberikan orang tua dipengaruhi oleh } \\
\text { berbagai faktor, seperti usia anak, } \\
\text { kondisi SES keluarga dan } \\
\text { pengalaman }\end{array}$ \\
\hline 5 & $\begin{array}{l}\text { Miragoli, S et al., } \\
\text { (2018) }\end{array}$ & $\begin{array}{l}\mathrm{N}=429 \\
\text { pasangan } \\
\text { suami istri } \\
\text { dengan rentang } \\
\text { usia anak dari } \\
1-6.5 \text { tahun }\end{array}$ & $\begin{array}{l}\text { Persepsi orang tua } \\
\text { tentang } \\
\text { permasalahan } \\
\text { perilaku anak, } \\
\text { stres pengasuhan } \\
\text { dan analisis data } \\
\text { diadik terkait sebab } \\
\text { dan akibat yang } \\
\text { terjadi }\end{array}$ & $\begin{array}{l}\text {-Persepsi orang tua terhadap anaknya } \\
\text { yang bermasalah berkorelasi positif } \\
\text { terhadap ketiga komponen dalam } \\
\text { stress pengasuhan (tekanan orang } \\
\text { tua, evaluasi hubungan antara orang } \\
\text { tua-anak yang lebih disfungsional } \\
\text { dan anak dianggap semakin sulit } \\
\text { dikendalikan) } \\
\text {-Stress yang dialami orang tua secara } \\
\text { signifikan berhubungan dengan } \\
\text { resiko kekerasan. }\end{array}$ \\
\hline 6 & $\begin{array}{l}\text { Maddison N. } \\
\text { Tolliver-Lynn, } \\
2020\end{array}$ & $\begin{array}{l}57 \text { orang tua } \\
\text { dari anak usia } \\
3-5 \text { th suku } \\
\text { Amerika } \\
\text { Indian / } \\
\text { Native Alaska }\end{array}$ & $\begin{array}{l}\text { Hubungan antara } \\
\text { orang tua-anak } \\
\text { terhadap stres } \\
\text { orang tua dan } \\
\text { permasalahn } \\
\text { perilaku anak }\end{array}$ & $\begin{array}{l}\text { Hubungan orang tua-anak } \\
\text { memoderasi hubungan antara gejala } \\
\text { kecemasan orang tua dan gejala } \\
\text { internalisasi anak, dan antara gejala } \\
\text { depresi orang tua dan gejala } \\
\text { internalisasi anak. }\end{array}$ \\
\hline 7 & $\begin{array}{l}\text { Berna Akçinar, } \\
2012\end{array}$ & $\begin{array}{l}655 \text { orang tua } \\
\text { dan anak usia } 6 \\
\text { tahun }\end{array}$ & $\begin{array}{l}\text { Latar belakang } \\
\text { keluarga terhadap } \\
\text { adapatasi sekolah }\end{array}$ & $\begin{array}{l}\text { Semakin tinggi tingkat sosio-ekonomi } \\
\text { orang tua maka semakin tinggi } \\
\text { tingkat kompetensi anak untuk dapat }\end{array}$ \\
\hline
\end{tabular}




\begin{tabular}{|c|c|c|c|c|}
\hline No & Nama Penulis & $\begin{array}{c}\text { Subjek } \\
\text { Penelitian } \\
\end{array}$ & Variabel & Hasil \\
\hline 8 & $\begin{array}{l}\text { Cong, X et al., } \\
(2020)\end{array}$ & $\begin{array}{l}\mathrm{N}=7120 \\
\text { usia lahir } \\
\text { sampai usia } 7 \\
\text { tahun }\end{array}$ & $\begin{array}{l}\text { dan karakteristik } \\
\text { perilaku anak } \\
\text { Keterlibatan orang } \\
\text { tua di masakecil, } \\
\text { depresi di awal } \\
\text { masa dewasa }\end{array}$ & $\begin{array}{l}\text { beradaptasi di kelas pertama sekolah } \\
\text { dasar } \\
\text {-Kenangan masa kanak-kanak dapat } \\
\text { berkontribusi pada resiko depresi } \\
\text { kemudian hari. Hal tersebut } \\
\text { terakumulasi melalui berbagai } \\
\text { pengalaman di awal kehidupan anak } \\
\text { saat mereka berada di tahap } \\
\text { perkembangan yang sensitif. } \\
\text {-Frekuensi, tipe dan intensitas } \\
\text { pengasuhan dapat berubah selama } \\
\text { anak mulai mandiri. Perubahan } \\
\text { perilaku pengasuhan di awal masa } \\
\text { kehidupan anak untuk lebih positif } \\
\text { akan berdampak pada menurunnya } \\
\text { resiko depresi anak di kemudian hari. }\end{array}$ \\
\hline 9 & $\begin{array}{l}\text { Joana M. Vieira, } \\
\text { Marisa Matias, } \\
\text { and Tiago } \\
\text { Ferreira }\end{array}$ & $\begin{array}{l}317 \text { orang tua } \\
\text { yang keduanya } \\
\text { bekerja dan } \\
\text { memiliki anak } \\
\text { prasekolah } \\
\text { berusia 3-6 } \\
\text { tahun }\end{array}$ & $\begin{array}{l}\text { Pengalaman negatif } \\
\text { dan positif } \\
\text { pekerjaan serta } \\
\text { peran kelurga } \\
\text { terhadap } \\
\text { permasalahn } \\
\text { perilaku anak }\end{array}$ & $\begin{array}{l}\text {-Orang tua yang mampu } \\
\text { menyeimbangkan pekerjaan dan } \\
\text { peran keluarga dikaitkan dengan } \\
\text { kualitas hubungan orang tua-anak, } \\
\text { yang pada saatnya berkaitan dengan } \\
\text { permasalahan perilaku ekternalisasi } \\
\text { dan internalisasi anak }\end{array}$ \\
\hline 10 & $\begin{array}{l}\text { Cameron L. } \\
\text { Neece, } \\
(2012)\end{array}$ & $\begin{array}{l}237 \text { anak usia } \\
3-9 \text { tahun } \\
\text { beserta orang } \\
\text { tua }\end{array}$ & $\begin{array}{l}\text { Stres pengasuhan } \\
\text { berkorelasi dengan } \\
\text { permasalahan } \\
\text { perilaku anak }\end{array}$ & $\begin{array}{l}\text { Permasalahan perilaku dan stres } \\
\text { pengasuhan secara signifikan } \\
\text { berdampak pada kedua kelompok } \\
\text { anak }\end{array}$ \\
\hline
\end{tabular}

Tabel 2. Artikel kualitas perkawinan dalam mengembangkan perilaku anak

\begin{tabular}{|c|c|c|c|c|c|}
\hline No & Nama Penulis & $\begin{array}{l}\text { Tahun } \\
\text { terbit }\end{array}$ & $\begin{array}{c}\text { Subjek } \\
\text { Penelitian }\end{array}$ & Variabel & Hasil \\
\hline 1 & Pedro et al., & 2012 & $\begin{array}{l}\mathrm{N}=519 \text { pasangan } \\
\text { yang menikah } \\
\text { atau kohabitasi }\end{array}$ & $\begin{array}{l}\text { Kepuasan } \\
\text { pernikahan, } \\
\text { coparenting, praktik } \\
\text { pengasuhan anak }\end{array}$ & $\begin{array}{l}\text { Coparenting memediasi } \\
\text { hubungan antara kepuasan } \\
\text { perkawinan pasangan dan } \\
\text { pengasuhan anak }\end{array}$ \\
\hline 2 & $\begin{array}{l}\text { Yuksel \& } \\
\text { Canel, }\end{array}$ & 2012 & $\begin{array}{l}\text { N=174 anak pra- } \\
\text { sekolah dan ibu }\end{array}$ & $\begin{array}{l}\text { kepuasan } \\
\text { pernikahan, } \\
\text { pendidikan pra- } \\
\text { sekolah }\end{array}$ & $\begin{array}{l}\text {-Kepuasan pernikahan mulai } \\
\text { menurun setelah kelahiran } \\
\text { bayi pertama. Sementara itu, } \\
\text { konflik antara pasangan } \\
\text { meningkat. } \\
\text {-Pasangan yang memiliki } \\
\text { anak prasekolah dan } \\
\text { mengalami kesulitan } \\
\text { beradaptasi dalam perannya } \\
\text { sebagai ayah dan ibu } \\
\text { membuat ikatan pernikahan } \\
\text { melemah }\end{array}$ \\
\hline 3 & Mccoy et al., & 2013 & $\begin{array}{l}235 \text { ibu, ayah, } \\
\text { dan } \\
\text { anak-anak usia } \\
\text { 5-7 tahun }\end{array}$ & $\begin{array}{l}\text { Konflik konstruktif } \\
\text { dan destrukstif } \\
\text { terhadap perilaku } \\
\text { sosial dan adaptasi } \\
\text { sekolah anak }\end{array}$ & $\begin{array}{l}\text { Konflik perkawinan yang } \\
\text { konstruktif dikaitkan dengan } \\
\text { praktik pengasuhan yang } \\
\text { positif, dan konflik } \\
\text { perkawinan yang destruktif } \\
\text { dikaitkan dengan praktik } \\
\text { pengasuhan yang lebih } \\
\text { negatif. }\end{array}$ \\
\hline
\end{tabular}


DOI: 10.31004/obsesi.v6i2.1561

\begin{tabular}{|c|c|c|c|c|c|}
\hline No & Nama Penulis & $\begin{array}{c}\text { Tahun } \\
\text { terbit }\end{array}$ & $\begin{array}{c}\text { Subjek } \\
\text { Penelitian }\end{array}$ & Variabel & Hasil \\
\hline 4 & $\begin{array}{l}\text { Stroud, C. B., } \\
\text { Meyers, K. M., } \\
\text { Wilson, S., \& } \\
\text { Durbin, C. E. }\end{array}$ & 2015 & $\begin{array}{l}\text { keluarga dengan } \\
\text { anak-anak usia } 3 \\
\text { hingga } 6 \text { tahun } \\
\text { (n=149; } 62 \% \\
\text { Kaukasia). }\end{array}$ & $\begin{array}{l}\text { Kualitas } \\
\text { Pernikahan, Anak } \\
\text { usia dini }\end{array}$ & $\begin{array}{l}\text { Fungsi pernikahan } \\
\text { berdampak pada penyesuaian } \\
\text { diri anak dan mempengaruhi } \\
\text { interaksi antara orang tua- } \\
\text { anak dalam konteks diad dan } \\
\text { triad }\end{array}$ \\
\hline 5 & $\begin{array}{l}\text { Frankel, L. A., } \\
\text { Umemura, T., } \\
\text { Jacobvitz, D., } \\
\text { \& Hazen, N. }\end{array}$ & 2015 & $\begin{array}{l}N=96 \text { pasangan } \\
\text { yang memiliki } \\
\text { anak usia } 8-24 \\
\text { bulan }\end{array}$ & $\begin{array}{l}\text { Konflik pernikahan, } \\
\text { Sosial emosional, } \\
\text { Pengaturan emosi }\end{array}$ & $\begin{array}{l}\text { Perkembangan emosi anak- } \\
\text { anak dipengaruhi oleh } \\
\text { interaksi keluarga di berbagai } \\
\text { tingkatan }\end{array}$ \\
\hline 6 & $\begin{array}{l}\text { Christopher, } \\
\text { C., Umemura, } \\
\text { T., Mann, T., } \\
\text { Jacobvitz, D., } \\
\text { \& Hazen, N. }\end{array}$ & 2015 & $\mathrm{~N}=96$ pasangan & $\begin{array}{l}\text { Coparenting, } \\
\text { Kepuasan } \\
\text { perkawinan } \\
\text { Konflik } \\
\text { perkawinan, } \\
\text { Transisi menjadi } \\
\text { orang tua }\end{array}$ & $\begin{array}{l}\text { Keterlibatan pengasuhan } \\
\text { yang rendah serta tingginya } \\
\text { konflik pernikahan pada } \\
\text { Ayah, menurunkan tingkat } \\
\text { coparenting }\end{array}$ \\
\hline 7 & $\begin{array}{l}\text { Robinson \& } \\
\text { Neece, }\end{array}$ & 2015 & $\begin{array}{l}\mathrm{N}=44 \text { orang tua } \\
\text { dari anak-anak } \\
\text { usia } 2,5 \text { hingga } \\
5 \text { tahun dengan } \\
\text { keterlambatan } \\
\text { perkembangan } \\
\text { dan masalah } \\
\text { perilaku tingkat } \\
\text { tinggi }\end{array}$ & $\begin{array}{l}\text { keterlambatan } \\
\text { perkembangan, } \\
\text { kepuasan } \\
\text { pernikahan, orang } \\
\text { tua } \\
\text { stres, masalah } \\
\text { perilaku }\end{array}$ & $\begin{array}{l}\text { Kepuasan pernikahan } \\
\text { berhubungan signifikan } \\
\text { dengan pola asuh dan } \\
\text { masalah perilaku anak, di } \\
\text { mana orang tua dengan } \\
\text { kepuasan perkawinan yang } \\
\text { lebih rendah melaporkan stres } \\
\text { pengasuhan yang lebih tinggi } \\
\text { dan masalah perilaku anak } \\
\text {-Kualitas perkawinan secara } \\
\text { signifikan memoderasi } \\
\text { perubahan masalah perilaku } \\
\text { anak }\end{array}$ \\
\hline 8 & $\begin{array}{l}\text { Elam, K. K., } \\
\text { Chassin, L., } \\
\text { Eisenberg, N., } \\
\text { \& Spinrad, T. } \\
\text { L. }\end{array}$ & 2017 & $\begin{array}{l}(\mathrm{N}=276) \\
\text { ibu, N 1/4 } 229 \\
\text { ayah) }\end{array}$ & $\begin{array}{l}\text { Stres perkawinan, } \\
\text { perilaku } \\
\text { eksternalisasi anak- } \\
\text { anak sebagai } \\
\text { prediktor, } \\
\text { pengasuhan ibu } \\
\text { dan ayah }\end{array}$ & $\begin{array}{l}\text { Perilaku eksternalisasi anak- } \\
\text { anak di masa kanak-kanak } \\
\text { tengah ditemukan lebih kuat } \\
\text { secara terbalik memprediksi } \\
\text { ibu 'versus ayah' pemantauan } \\
\text { pada remaja awal. Sebaliknya, } \\
\text { tekanan perkawinan lebih } \\
\text { kuat memprediksi } \\
\text { pemantauan ayah yang } \\
\text { rendah dibandingkan ibu. }\end{array}$ \\
\hline 9 & $\begin{array}{l}\text { Hanetz } \\
\text { Gamliel et al., }\end{array}$ & 2018 & $\begin{array}{l}\mathrm{N}=60 \text { keluarga } \\
\text { yang memiliki } \\
\text { anak usia 3-5 } \\
\text { tahun }\end{array}$ & $\begin{array}{l}\text { Kecemasan orang } \\
\text { tua, Kualitas } \\
\text { pernikahan, } \\
\text { Perilaku } \\
\text { eksternalisasi anak, } \\
\text { Perilaku } \\
\text { internalisasi anak }\end{array}$ & $\begin{array}{l}\text { Ketidakpuasan perkawinan } \\
\text { ibu dan ayah sebagian } \\
\text { dimediasi oleh hubungan } \\
\text { antara kecemasan ibu dan } \\
\text { perilaku anak }\end{array}$ \\
\hline 10 & Fan et al., & 2020 & $\begin{array}{l}\mathrm{N}=714 \text { keluarga } \\
\text { dengan anak- } \\
\text { anak prasekolah }\end{array}$ & $\begin{array}{l}\text { Temperamen Anak, } \\
\text { Kualitas } \\
\text { Perkawinan, } \\
\text { Coparenting } \\
\text { Keluarga } \\
\end{array}$ & $\begin{array}{l}\text { Kualitas pernikahan tidak } \\
\text { memoderasi hubungan antara } \\
\text { temperamen anak dan } \\
\text { coparenting, }\end{array}$ \\
\hline
\end{tabular}

